\title{
ORGANIZACIÓN TERRITORIAL Y SEÑORIALIZACIÓN EN EL VALLE DE FENAR (SIGLOS XI-XVI)
}

\author{
JUAN JOSÉ SÁNCHEZ BADIOLA
}

\section{Resumen}

Se analiza aquí la evolución histórica de un territorio medieval, el Valle de Fenar, desde la concesión de su célebre fuero por Fernando I, en 1042 , hasta el conflictivo proceso de señorialización que experimenta durante la Baja Edad Media y el siglo XVI.

Palabras clave les.

fueros, organización territorial, señorialización, conflictos señoria-

\begin{abstract}
In this article, it's analyzed the historical evolution of a medieval territory, the "Valle de Fenar», since the concession of its own «fuero» by Ferdinand III, in 1042, to the seignorial conflicts that experiments during the late Middle Ages and the 16th century.
\end{abstract}

Key words

fuero, territorial organization, feudalism, manorial conflicts.

\section{Los orígenes del territorio}

Los orígenes históricos del Valle de Fenar presentan una dificultad notable en comparación con otros territorios vecinos, cual es la absoluta carencia de noticias fiables acerca del mismo durante toda la Alta Edad Media ${ }^{1}$. Silencio que no debe atribuirse a una despoblación del territorio, ya que la abundancia de asentamientos castreños y restos romanos parecen indicar un poblamiento relativamente próspero desde la Antigüedad ${ }^{2}$. Probablemente, al tratarse de un pequeño valle transversal entre las cuencas del Bernesga y el Torío, desprovisto de relevancia estratégica, se desenvolvería en una relativa tranquilidad hasta la plenitud medieval, cuando iría ganando en importancia, más por sus henales, a los

\footnotetext{
${ }^{1}$ J. RodRíGUEZ FERnÁNDEZ, «El Municipio de La Robla. Antecedentes históricos y signos heráldicos», Tierras de León $(=T L), 60,1985$, pp. 79-88, p. 84, recoge como primera mención de este valle una venta de 965, pero ésta se refiere, en realidad, a Fontecha (E. SÁEZ, C. SÁEZ, Colección documental del Archivo de la Catedral de León (775-1230), vol. II (953-985), León, 1990 (=CCL), doc. 391).

2 J. A. GutiérRez GonzÁLEZ, Poblamiento antiguo y medieval en la montaña central leonesa, León, 1985. J. M. GonzÁlez García, J. Miranda PÉrez-SeOANE, «El Valle de Fenar: contribución al estudio de su poblamiento antiguo y medieval», $T L, 76,1989$, pp. 69-98.
} 
que debe el nombre, que por otro tipo de necesidades militares o administrativas.

Es de suponer que, hasta su organización como territorio, la comarca fenariega estuviese adscrita a alguna de las demarcaciones vecinas, aunque carecemos de indicios claros al respecto. El espacio que delimita el fuero leonés de 1017 en torno a la capital, a modo de primitivo alfoz, deja fuera el Valle de Fenar ${ }^{3}$, que tampoco parece relacionado con los distritos de Alba y Gordón, ni con el del cercano castillo de San Salvador de Curueño y sus mandaciones de Pedrún y Ferreras ${ }^{4}$. En 1002, el obispo leonés Froilán II dona a su sede el «...locum uocabulo Sancta Maria in Mazanata... et suo mandamento qui est sursum inter alpibus uocabulo Orzenaga secundum consuetudinem seruientem ad hunc locum» ${ }^{5}$, y medio siglo después, sabemos que el abad de San Pelayo de León era tenente del mandamento de Torío ${ }^{6}$, pero no nos consta la vinculación de Fenar a ese territorio, como tampoco al de Cervera, donado por Alfonso VI a San Pelayo y San Isidoro en 1103, con todo su mandamento ${ }^{7}$, ni al territorio de Robras mencionado en 1128, suponemos que en referencia a Robles, en el que se sitúa la villa llamada Illa Fonte Aluea ${ }^{8}$.

Si dejamos aparte un documento fechado en 1002 de difícil interpretación ${ }^{9}$, la primera referencia documental al área fenariega sería el propio fuero de 1042, por el que Fernando I y doña Sancha delimitan el marco de sus relaciones con las gentes del valle, perteneciente a su realengo, a la par que señalan algunas directrices de tipo jurídico y administrativo. Sin embargo, el hecho de que la redacción del documento corresponda a la segunda mitad del siglo XII, siendo no pocos los anacronismos lingüísticos, jurídicos y prosopográficos; unido a la falta de menciones de esta comarca hasta los años centrales de la citada centuria, proyectan la sombra de la duda sobre la paternidad de la propia carta ${ }^{10}$. Esta, sin

\footnotetext{
${ }^{3}$ El límite del alfoz iba, en esta zona, «...per Uillam Felicem (Villafeliz de la Sobarriba) et per illas Milieras (Milleras, en Pardavé), et per Cascantes, per Uillam Uellite (en Villadangos)...» (J. RodRíGUEZ FERNÁNDEZ, Los fueros del reino de León, León, 1981 (=FRL), II, doc. 2).

${ }^{4}$ CCL, doc. 300. J. M. RUIZ AsEnCiO, Colección documental del Archivo de la Catedral de León (775-1230), vol. III (986-1031), León, 1987 (=CCL), docs. 588-589.

${ }^{5}$ CCL, doc. 629.

${ }^{6}$ J. M. RuIZ AsEncio, Colección documental del Archivo de la Catedral de León (775-1230), vol. IV (9861031), León, 1989 (=CCL), docs. 1084-1085.

${ }^{7}$ E. Martín LópeZ, Patrimonio cultural de San Isidoro de León. Documentos de los siglos X-XIII, León, 1995 (=CSIL), doc. 12. La cesión ess confirmada por Fernando II en 1181 (CSIL, doc. 125).

${ }^{8}$ S. DOMínGUEz SÁNCHEZ, Colección documental del monasterio de Santa María de Carbajal (1093-1461), León, 2000 (=SMC), doc. 6.

${ }^{9}$ Se trata de la venta de una viña en Villaseca de la Sobarriba, entre cuyos linderos se cuenta otra de Uigila que fuit de Fenale (CCL, doc. 622).

${ }^{10}$ CCL, doc. 997.
} 
perjuicio de que existiera algún precedente de época de Fernando I, y al igual que el Fuero de Valdesaz, atribuido a la reina doña Sancha, pudo redactarse durante el reinado del Emperador, coincidiendo con su política de reorganización del realengo, a fin de regular una serie de prestaciones que ya vendrían realizándose desde tiempo inmemorial. Pero de ello nos ocuparemos más adelante.

En 1063, Fernando I y doña Sancha donaban a San Juan Bautista de León una villa situada in riuulo Torío, llamada Fenales, la cual antes habían permutado con el abad Froila de dicho monasterio, junto con Toral, a cambio de Congosto, en El Bierzo, y una villa en Valdehunco ${ }^{11}$. La entidad de la villa de Fenales se ha interpretado más bien como una gran posesión o hereditas, que se referiría no a un núcleo de población concreto, sino a todo el valle o parte de él. En apoyo de esta tesis estaría la descripción que hace del mismo el Becerro de presentaciones leonés, que recoge, junto a las parroquias de Rabanal y La Ylze, las de San Salvador de Fenal y Fenal, ésta dedicada a San Cristóbal y Santa María ${ }^{12}$, dando la impresión de que alude, de forma conjunta, a Robledo, Naredo y Sola$\mathrm{na}^{13}$. Probablemente se trató de un ejemplo más de valle-villa o locumvilla, esto es, un poblamiento organizado a partir del espacio del valle y que expresa igualmente su entidad jurídica y comunitaria mediante el término villa, fenómeno muy frecuente en la Alta Edad Media leonesa, y que a menudo termina convirtiéndose en una unidad administrativa. Dentro de ese marco se desenvuelven las actividades de una comunidad aldeana relativamente dispersa en diferentes asentamientos familiares a los que se denomina igualmente «villas», que suelen conocerse por el nombre de su propietario, aunque es frecuente también que adopten el de todo el conjunto, con lo que no es algo inusual que aparezcan varias donaciones o compraventas distintas de villas con idéntica denominación, induciendo a menudo a confusión, ni tampoco que el valle pase a considerarse «villa» en su totalidad, y que, habida cuenta de la variedad de núcleos en él existentes, su nombre aparezca en plural.

Las unidades dispersas que recoge la documentación como villas, cortes o heredades tenían, como es lógico, una extensión y un capital productivo muy diferente según los casos. Las que pertenecían a presores destacados estaban más distanciadas entre sí, ya que acumulaban mayor cantidad de espacio, y solían contar con sus propios templos y con recur-

\footnotetext{
${ }^{11}$ CSIL, doc. 6.

12 J. A. FERNÁNDEZ FLÓREZ, op. cit., p. 410.

${ }^{13}$ J. M. GONZÁLEZ, J. MiRANDA, op. cit., p. 93.
} 
sos suficientes para dar origen a una aldea. La mayoría de los asentamientos, por contra, eran mucho más modestos y se situaban en torno a las iglesias u otros puntos de referencia, tendiendo a acercarse entre sí y mantener lazos de tipo comunitario. Este fenómeno es más frecuente en la Montaña, donde se advierte una cierta dificultad en la concentración y consolidación de los bienes necesarios para dar origen a una gran villa particular diferenciada que, a su vez, evolucione hacia la aldea. Como consecuencia de todo ello, y seguramente de una mayor densidad demográfica de la región en los inicios de la Alta Edad Media, los topónimos formados a partir de villa- más nombre de posesor son escasos aquí, en comparación con los páramos. Abundan en cambio los que se refieren a las condiciones naturales de los loca o espacios concretos del término donde se va concentrando la población, los cuales, a menudo, constituyen fases intermedias en el proceso, de forma que se van definiendo progresivamente nuevos núcleos aldeanos hasta ajustarse a las necesidades impuestas por las nuevas formas de producción y el crecimiento demográfico, resultando un hábitat más concentrado y con un término de menor radio y bien delimitado, facilitándose así el desplazamiento a las zonas de labor y la especialización de éstas.

Así pues, la villa de Fenar constituiría originariamente una unidad de poblamiento que abarcaría todo el valle, lo que explica que su nombre aparezca en plural —ualle de Fenales, en $1176^{14}$ - por los diversos asentamientos que existen en su término; que, en 1117, se cite la villa de Rabanal dentro del mismo ${ }^{15}$; que el asentamiento principal, villa dominica, palatium... adopte el nombre del conjunto, Fenal, quizá concretándose en el oriente del término, si hacemos caso a los datos del Becerro y topónimos como «Fuente Fenar», entre Robledo y Naredo...; e, incluso, que de ella surgiesen nuevos núcleos en loca menores como Naredo, Robledo, Otero, Solana...; o en torno a los templos de San Torcuato o San Salvador de Fenal, que pasaría a denominarse San Salvador de Naredo en atención a su ámbito más inmediato, habiéndose diferenciado ya dentro de Fenal otras aldeas y collaciones.

La donación de Fernando I en favor de San Isidoro, como la que hace su nieta en Rabanal, seguramente se referían a posesiones directas del rey dentro del término, la reserva, los derechos económicos sobre las explotaciones campesinas, las sernas. Un conjunto que, a juzgar por el

\footnotetext{
${ }^{14}$ CSIL, doc. 115 .

${ }^{15}$ CSIL, doc. 16.
} 
texto foral, torna a la Corona, salvo algunas heredades, como la del $f a-$ brum Cipriano que dona Fernando II a la obra de San Isidoro, para que le sirva junto con su familia ${ }^{16}$. El privilegio de Alejandro III a favor de dicha institución, fechado en 1176, se limita a consignar en la comarca la hereditate que spectat ad opus Sancti Ysidori ${ }^{17}$.

\section{El fuero de Fenar}

Nos hemos referido ya a los problemas de datación que presenta el fuero fenariego, y sugerido la etapa de Alfonso VII como la de su posible redacción, a partir de la cual el valle comienza a tener una presencia significativa en la documentación leonesa. Unos problemas que han incidido de forma notable en el análisis e interpretación del propio texto, por otra parte difícil e intrincada. J. Rodríguez se extraña de que aquél, en extremo sencillo y de escasa calidad literaria y gramatical, guarde tan poca relación con el fuero leonés de 1017, aun reconociendo lo diferente de sus ámbitos geográficos. Supone este autor que ello se debería a que Fernando I consideró innecesario reiterar en el texto fenariego las normas presentes en el de León, dándolas por sobreentendidas y concentrándose en aspectos específicos del Valle de Fenar ${ }^{18}$, algo en lo que no está de acuerdo Sánchez-Arcilla, creemos que acertadamente, dado el contenido de ambos. Coinciden los dos autores en señalar, como antes Díez Canse$\mathrm{co}^{19}$, el carácter eminentemente rural del fuero de Fenar, centrado sobre todo en las relaciones entre el rey y las gentes del valle. El texto está muy relacionado con los que podríamos denominar «fueros de la tierra», destinados a unidades como la que nos ocupa, carentes de un centro militar definido y que constituyeron en origen un poblamiento de valle. A menudo son regiones en las que la documentación deja traslucir una clara sensación de atraso o arcaísmo, comarcas agrestes y de difíciles características climáticas o edáficas, pero también territorios reducidos que era necesario regular o reorganizar, y donde existían muy determinados intereses regios. La política foral de los monarcas, interesada en el desarrollo y la mejor explotación del realengo, se dirige a la tierra como conjunto $\mathrm{y}$ a un concilio territorial cuyas competencias son escasas $^{20}$, y se ocupa de ordenar la vida comunitaria, conceder algunas exenciones favorables a

\footnotetext{
${ }^{16}$ CSIL, doc. 90.

${ }^{17}$ CSIL, doc. 115 .

${ }^{18}$ FRL, I, p. 115.

${ }^{19}$ L. DíEZ CANSECO, «Sobre los fueros del Valle de Fenar, Castrocalbón y Pajares. Notas para el estudio del Fuero de León», Anuario de Historia del Derecho Español, I, 1924, pp. 337-381.

${ }^{20}$ FRL, II, doc. 71 .
} 
la población, $\mathrm{y}$, de forma especial, estimular las producciones específicas de la región, sean cinegéticas, silvícolas, mineras o, como en nuestro caso, de tipo agropecuario.

En este sentido, el fuero de Fenar regula las sernas u operae que los naturales deben hacer en la reserva regia, básicamente segar el heno cada año, comprometiéndose el monarca a darles comida y bebida, y un día al año las mieses. Además, debían pagar como censo o infurción por sus heredades 18 dineros cada marzo. El rey, por su patronato sobre las iglesias del valle, recibía de los clérigos que las gobernaban dos lomos, una gallina, un pan, media terraza de vino o de sidra y, a la muerte de cada uno de ellos, un buey. Asimismo, se regulan las transmisiones de heredades y la movilidad campesina, algo usual en la época, dado que la preocupación fundamental es no tanto mantener en las explotaciones a unos campesinos concretos, como asegurar que aquéllas permanezcan activas y generando renta. Lo más habitual es que el señor deje libertad de movimiento al campesino, que podrá vender el préstamo entero o en parte siempre y cuando se asegure el seruitium, esto es, que el adquirente siga cotizando por la tierra y no sea vasallo de otro ni exento ${ }^{21}$. A veces los fueros conceden un breve plazo de tiempo, normalmente nueve días, para que el campesino pueda liquidar sus cosas y abandonar la heredad, como sucede en el de Valdesaz, que le reconocía, además, la mitad del valor de las roturaciones, palomares o huertas tapiadas que hubiese hecho. A partir de mediados del XII parecen endurecerse un tanto las condiciones, y así, el fuero de San Pedro de las Dueñas (1162) penaliza el abandono de la heredad con 60 sueldos, perdiendo sus derechos el campesino si iba a Grajal u otro lugar, salvo que dejase casa en San Pedro y cotizase por ella ${ }^{22}$. Otros recursos fueron la penalización del abandono con la mitad de la heredad o con su completa pérdida; y permitir la compra de heredades solamente a los vasallos, prohibiéndosela a hidalgos y clérigos, y dando a menudo preferencia al señor.

En Fenar, el campesino que habitaba en su heredad podía venderla por completo, salvo la casa y la era, siempre y cuando morase en ella - y siguiera cotizando-, pero si no quería habitarla, debía dar al rey la tercera parte de dicha heredad. Mayores dificultades presentan los siguientes capítulos: "Si in palacio iacuerit et uoluerit extahere, det uno carnero, ex extrahat illam; similiter teneat homines subter se quos uolue-

\footnotetext{
${ }^{21}$ FRL, II, docs. 28, 33, 46, 49, 56.

${ }^{22}$ FRL, II, 27.
} 
rit. Si redire uoluerit in aliam partem extra domum liminaribus, non habeat potestatem super corpus eius, set habeat in rebus suis». J. Rodríguez veía aquí una referencia a quienes morasen o sirviesen en palacio a los tenentes o vílicos y quisiesen sacar su heredad, mientras que la posibilidad de tener campesinos bajo dependencia se extendería a todos los fenariegos. A continuación, el texto estaría hablando de aquellos campesinos dependientes que quisieran volver a su lugar de origen, de forma que, según su lectura, non habeant poder sobre su cuerpo, sino que sólo puedan retener los bienes muebles, aunque duda de si el extra domum liminaribus alude a la casa de su señor o a la de procedencia del campe$\operatorname{sino}^{23}$. Sánchez-Arcilla interpreta este capítulo como la compensación que el campesino que vive en palacio o está vinculado a él ha de dar para abandonar la heredad, y apunta la posibilidad de que la segunda parte se refiera al tenente regio ${ }^{24}$. En este caso, se trataría de campesinos vinculados personalmente a palacio y que explotarían la reserva ${ }^{25}$, cuya situación vendría el fuero a mejorar; algo parecido a lo que vemos en el de Valdesaz, cuando se refiere al villanum sedentem ad mensam cum suo seniore, el cual podía abandonar a éste cuando quisiere, disponiendo de nueve días para llevarse sus bienes, sin que el señor pudiera ponerle la mano encima $^{26}$. El fuero de Fenar prevería el caso de los que deseasen luego volver a otra parte fuera de la casa de origen, aunque la literalidad de la frase parece indicar lo contrario de lo que entiende J. Rodríguez, ya que su lectura más reciente es habeat y no habeant, cuyo sujeto sería el campesino que quiere regresar y que, de este modo, carecería de potestad sobre su cuerpo — sería nuevamente dependiente-, pero sí sobre sus bienes $^{27}$. Y aún cabe otra posibilidad más, que el término iacuerit, en concordancia con su uso más frecuente en la documentación, aluda a la heredad, y no a un individuo, lo que explicaría el sentido de la expresión extrahat illam - no extrahat illa, como leen los citados autores-, donde illam es claramente complemento directo. En tal caso, el texto se refiere a la heredad que permanece o ha caído en palacio, la cual puede ser recu-

\footnotetext{
${ }^{23}$ FRL, I, p. 117. El fuero de San Tirso y Castrillino permitía en tales casos a los campesinos volver sin penalización alguna (FRL, II, 61).

${ }^{24}$ J. SÁNCHEZ-ARCILLA, «El derecho especial de los fueros del reino de León (1017-1229)», El reino de León en la alta Edad Media, II: Ordenamiento jurídico del reino, León, 1991, pp. 310-311.

${ }^{25}$ Quizá similares a los juniores de cabeza, cuya dependencia personal del señor les impedía abandonarle (C. DE AYAla MARTínEZ, «Relaciones de propiedad y estructura económica del Reino de León: los marcos de producción agraria y el trabajo campesino (850-1230)», El Reino de León en la Alta Edad Media, VI, León, 1994, pp. 135-410, pp. 337-339 y 401).

${ }^{26}$ J. M. a FeRnández CATÓN, Colección documental del Archivo de la Catedral de León (775-1230), vol. V (1109-1187), León, 1990 (=CCL), doc. 1131.

${ }^{27}$ El fuero de San Miguel de Escalada permite al señor prendar los ganados de quien no dé fiador cuando demande caloña, y, si no los tuviere, prendarle el cuerpo (FRL, II, 38).
} 
perada para préstamo mediante el pago del carnero $^{28}$, y su tenente explotarla teniendo subter se a los hombres necesarios.

Para finalizar con el asunto de la movilidad campesina, el fuero permite conservar su heredad a quienes se desplacen a Torío y Cervera, no tanto para mantener una teórica solidaridad entre tales territorios y Fenar $^{29}$, cuanto por su cercanía, facilitándose el mantenimiento de las explotaciones fenariegas ${ }^{30}$. Quizá también, al menos en origen, porque todos estos territorios pertenecían al realengo, puesto que se establece que el campesino trasladado haga con ella el foro del lugar que habitare; de no ser así, sería hallado fugitivo y sólo podría disponer de los bienes muebles.

Cuanto acabamos de ver parece confirmar el carácter rural de del fuero, muy alejado de los principios que establece el leonés de 1017, que responden ya, siquiera de forma embrionaria, a algunas de las características fundamentales de las cartas pueblas que se extenderán en los dos siglos posteriores ${ }^{31}$, abriendo un largo proceso que culmina en lo que se ha dado en llamar «sistema concejil»»" Los concejos, como personas jurídicas, pasan a ejercer unas determinadas funciones señoriales sobre las villas de sus alfoces, desarrollando sus propios mecanismos administrativos, bien se trate de una transferencia en favor del concejo de atribuciones similares a las de los tenentes y señores, bien de un estado de cierto equilibrio entre las competencias concejiles y las que se reserva el $p a-$ latium, de mucho mayor peso en el caso de los señoríos.

Ciertamente, el fuero fenariego está lejos de estos supuestos, pero tampoco puede considerarse una simple carta de población, sino que, en algunos puntos, parece ocupar una posición intermedia entre los fueros rurales y los de carácter más urbano. Aunque se desentiende de asuntos relativos a la constitución de una puebla o burgo, tanto el protocolo como el último capítulo presentan la novedad dirigirse uobis concilio de Fenar, reconociendo a éste como representante jurídico del territorio; por otro lado, junto a la existencia de tenentes, se conceden al concejo determina-

\footnotetext{
${ }^{28}$ El fuero de San Tirso y Castrillino disponía que quien abandonase el lugar, pagara su censo y dejara la heredad en palacio (FRL, II, 61). Los vasallos de San Pedro de Montes en Noceda podían tener sus casas populatas de homines quops ipsi voluerint, siempre que cumpliesen sus obligaciones forales (FRL, II, 17).

${ }^{29}$ FRL, I, 117.

${ }^{30}$ J. SÁNCHEZ-ARCILlA, Op.cit., pp. 185-380, p. 310.

31 J. I. RUIZ DE LA PEÑA, «Los procesos tardíos de repoblación urbana en las tierras del norte del Duero (siglos XII-XIV)», Boletín del Instituto de Estudios Asturianos, 88-89, 1976, pp. 735-777, p. 770.

${ }^{32}$ Vid. J. M. Monsalvo ANTÓN, «Concejos castellano-leoneses y feudalismo (siglos XI-XIII). Reflexiones para un estado de la cuestión», Studia Historica. Historia Medieval, X, 1992, pp. 20-243.
} 
das competencias forales, jurisdiccionales y administrativas, aunque no se especifican, e incluso se establece un lugar fijo para sus reuniones: Concilio isto debet se congregare in Uerruga pro suis foros et cuntas et iudicios et totos suos directos, ampliando así las competencias de los viejos concilia de boni homines. No hallamos todavía referencia alguna a los límites concejiles ni a la constitución de mercado, aunque no deja de ser significativa la alusión en 1225 a una Ualina de Mercato - «Vallina Mercao», entre Rabanal y Candanedo-, pese a carecer de carácter propiamente urbano ${ }^{33}$.

\section{Territorio y tenencia}

La extensión territorial del Valle de Fenar puede deducirse de la relación de villas incluidas en su jurisdicción a lo largo de los siglos XII y XIII' ${ }^{34}$ Rabanal, en $1117,1177,1225^{35}$; Candanedo, en 1161, 1172, 1179,1220 y $1221^{36}$; Brugos, en 1177 y $1215^{37}$; Robledo, en 1177, 1221 y 1276 ${ }^{38}$; San Torcuato, Solana y Otero, en $1221^{39}$; La Ilce, en $1221^{40}$; Fe-

\footnotetext{
${ }^{33}$ J. M. a FernÁndez CATÓn, Colección documental del Archivo de la Catedral de León (775-1230), vol. VI (1188-1230), León, 1991 (=CCL), doc. 1927. C. ÁlvAREZ, J. J. SÁNCHEZ BADIOLA, «El fenómeno urbano en la Edad Media leonesa», El fenómeno urbano medieval entre el Cantábrico y el Duero, Santander, 2001, pp. 321-361.

${ }^{34}$ No incluimos el Castillo de San Salvador (M. GonZÁlez FlóREZ, La ribera del Torío, León, 1982, p. 246), La Oja (J. A. GUTIÉRREZ, op. cit., p. 128) ni Villa Abdela (J. RodRÍGUEZ, «El Municipio de La Robla», p. 84, de donde lo han tomado sin verificación alguna J. A. GUTIÉRREZ, op. cit., p. 128, y J. J. SÁNCHEZ BADIOLA, La comarca de La Robla, valles de Alba y Fenar, León, 1985, p. 51), que nunca estuvieron en esta comarca (J. M. GonZÁleZ, J. MiRANDA, op. cit., pp. 94-96). Tampoco «Compostizo, en el ayuntamiento de Naredos» (P. AlbANO, "Canteros de Naredo en la obra del puente de San Marcos», La voz del Torío-Porma-Curueño, 4, 1989, pp. 14-15), que se halló realmente en la yunta de Cudeyo, merindad de Trasmiera, en Cantabria (J. J. SÁNCHEZ BADiOLA, Alba y Fenar, León, 1995, p. 70).

${ }^{35}$ CCL, docs. 1603, 1927. CSIL, doc. 16.

${ }^{36}$ CCL, docs. 1574, 1892, 1896, 1980. V. VignaU, Cartulario del Monasterio de Eslonza, Madrid, 1885, doc. C.

${ }^{37}$ CCL, docs. 1603 y 1846. J. RodRÍGUEZ, «El Municipio de La Robla», pp. 83-84, apunta la posiblilidad de que sea el Uerruga del Fuero de 1042, aunque éste no necesariamente tuvo que ser un poblado, sino un paraje. Tal identificación tiene la dificultad de que Brugos se encuentra en el extremo oeste del valle, y la tradición comarcal sitúa el punto de celebración de los concejos en Candanedo, según el citado autor. Vid. también J. M. GONZÁLEZ, J. MIRANDA, op. cit., pp. 77-78. En nuestra opinión, y por las razones que más adelante iremos viendo, habría que situarlo en el «Alto Rajón», donde estuvo la iglesia de San Cristóbal de Solana, primitiva parroquia de Fenar y lugar real de las reuniones concejiles del valle.

${ }^{38}$ CCL, docs. 1603, 1901, 2367.

${ }^{39}$ CCL, doc. 1901. Sobre Otero: J. RodríGuEZ, «El Municipio de La Robla», p. 84 y J. M. GonZÁLEZ, J. MirAndA, op. cit., pp. 80-81. San Torcat es situado por J. RodRígUEZ, op. cit., p. 84, en Solana de Fenar, citando la existencia reciente de una ermita modesta dedicada a ese santo «en el lugar que la tradición perpetúa como asiento del viejo poblado, y que ella era objeto de notable veneración en la comarca». M. GONZÁLEZ FLÓREZ, La ribera del Torío, León, 1982, p. 247, y A. GUTIÉRREZ, op. cit., p. 160, parecen inclinarse por lo que denominan «El Torreón» y «El Convento» («Alto Rajón», en Solana). J. M. GonZÁlEZ, J. MiRANDA, op. cit., pp. 79-81, también lo localizan en ese lugar, donde estaba la ermita de San Torcuato, ya desaparecida. A nuestro juicio, sólo pudo hallarse en el paraje en torno a la parroquia de Robledo, dedicada a San Torcuato y antiguo santuario (J. J. SÁNCHEZ BADIOLA, Alba y Fenar, pp. 58-60. Archivo Histórico Diocesano de León (=AHDL), F. Beneficial, c. 13065 y 14760. Archivo Histórico Provincial de León (=AHPL), Catastro del M. de la Ensenada (=CME), Robledo), correspondiendo las ruinas del «Alto Rajón», en Solana, a la de San
} 
rrones, en $1225^{41}$; y Naredo o San Salvador de Neredo, en 1176, 1289 y $1299^{42}$. Como puede comprobarse, el territorio viene a coincidir en lo fundamental con el demarcado por Alfonso X en $1254^{43}$.

La política de reorganización del realengo supuso una transformación importante de los mecanismos de administración territorial, fundamentalmente la adopción del sistema tenencial, que permitía una más estrecha vinculación a la Corona de una aristocracia territorial que va a partir de ahora a rotar por las tenencias, evitándose así su arraigo y reforzándose la concepción beneficial de los cargos y la nobleza de servicio. Paralelamente se irá desarrollando una amplia red de merinos o vílicos que actúan como delegados directos del rey en los territorios, y que tuvieron en principio un carácter más funcionarial y cercano al monarca que los tenentes. Éstos reciben territorios en beneficio a condición de que los gobiernen y defiendan, aquéllos representan los intereses del realengo no transferidos en dichos territorios, o bien administran otros que dependen directamente del trono. Se trata de un proceso lento y complejo que culmina en época de Alfonso IX con la consolidación de la supremacía jurisdiccional regia y la instauración definitiva de la merindad mayor, con su jerarquía administrativa propia.

Estas transformaciones son evidentes también en el territorio de Fenar, donde el fuero recoge la figura del homo qui tenuerit illa terra, el cual debería satisfacer anualmente al rey un yantar: un pan, un tocino, dos carneros, una gallina, tres cañadillas de vino, dos libras de cera, una

\footnotetext{
Cristóbal que cita el Becerro (J. A. FERnÁndEZ FlóREZ, «El Becerro de Presentaciones, Códice 13 del Archivo de la Catedral de León. Un parroquial leonés de los siglos XIII-XIV», León y su historia, vol. V. Miscelánea histórica de temas leoneses, León, 1984, pp. 265-565, p. 410), junto a la que existe un pago denominado «Solaiglesia», y cuyo término abarcaba por igual Solana y Robledo.

${ }^{40}$ CCL, doc. 1896. En Candanedo (J. M. GonZÁlez, J. MirandA, op. cit., p. 93. J. J. SÁnchez Badiola, Alba y Fenar, pp. 61-62).

${ }^{41}$ CCL, doc. 1933. Localizado en Rabanal (J. RodRÍGUEZ, «El Municipio de La Robla», p. 84. J. M. GonZÁLEZ, J. MIRANDA, op. cit., p. 78).

${ }^{42}$ CCL, docs. 2367, 2531. CDC, doc. 573. CDG, doc. 550. J. M. GONZÁleZ, J. MiRANDA, op. cit., pp. 81-82, piensan que fueron dos lugares diferentes, Naredo, en el emplazamiento actual, y San Salvador, en «El Cuarto», paraje al norte del término; en nuestra opinión, se trata de un mismo lugar, siendo San Salvador la actual parroquia, como se ve en la donación que hace en 1276 doña Sancha, hija de Rodrigo Fernández de Valduerna y «señora del heredamiento de don Ramiro, mio hermano, e cumplidor de la sua manda», de su heredad en Naredo, Robledo y demás lugares de Fenar a la sede legionense (J. J. SÁNCHEZ BADIOLA, Alba y Fenar, p. 62. J. M. RuIZ ASENCIO, J. A. MARTín FuERTES, Colección documental del Archivo de la Catedral de León, vol. IX (1269-1300), León, 1994, doc. 2367), bienes que la iglesia da en préstamo a Ramiro Díaz, el cual, al devolverlos en 1289, los sitúa en Fenal, en el lugar de san saluador de neredo (Ibid, doc. 2531).

43 «...conçeyo de ffenar... iaz entre tales términos. perlla cruz de vega de milleras. Eperlla Riba de arenas. Eperlla Riba de tanba. Epella Riba de utrera» (J. M. GonZÁlez GARCíA, M. ${ }^{a}$ T. LlamAZARES PrIETO, J. MiRANDA PÉREZ-SEOANE, «Límites medievales del concejo de Fenar. Estudio histórico-lingüístico», TL, 69, 1987 , pp. 69-98).
} 
de pimienta y dos estopos de cebada ${ }^{44}$. Igualmente, aparece el villicus o maiorinus nombrado por el rey; a él van las denuncias y corresponde la autoridad jurisdiccional, percibiendo el iudicato o costas. Al cesar, debía dar al monarca un buey, y restituir doblado el daño que injustamente hubiera originado, del mismo modo que el quartador o recaudador entregaría a su cese un carnero, respondiendo de los perjuicios causados. Además, si otro merino de fuera entrase en el distrito y resultase muerto, los fenariegos solamente pagarían por ello tres arienzos.

Sin embargo, las primeras noticias que tenemos acerca de los tenentes y merinos de Fenar datan de época de Fernando II y Alfonso IX. Aunque ya confirma un documento de 1177 referente al territorio ${ }^{45}$, es en 1186 cuando aparece Pelayo Tablatelo de forma expresa como tenente de la mitad de Fenar. Ese año, Fernando II entrega la otra mitad del valle a la Orden de Santiago y a su maestre don Fernando Díaz, con todos sus términos y pertenencias, entradas y salidas, montes, valles, ríos y pastos $^{46}$. En 1215 se cita a Abril Rodríguez como dominante in Fenar, con su merino Domingo Gordo ${ }^{47}$, y durante 1219 como tenente Fenar, siendo merino Domingo Pérez, y merino de la obra de la catedral Pelayo Gil' ${ }^{48}$; Diego Martínez es mencionado también en 1223, de forma retrospectiva, como su merino ${ }^{49}$. Este don Abril se dice en 1220 y 1221 hijo de Rodrigo Abriles, que tenía ya posesiones en el Valle de Fenar y otras comarcas vecinas, entre ellas una heredad en Candanedo, que incluía parte en la iglesia y las dos devesas de Rouredello, más otra en el mismo lugar denominada Donga, esto es, Dominica, sin duda de procedencia regia, por lo que cabe suponer que habría ejercido también la tenencia ${ }^{50}$. Don Abril es uno de los principales donantes y vendedores de bienes a la obra de la catedral leonesa, recibiéndolos todos ellos del obispo en prestimonio vitalicio en $1221^{51}$. Aparte, la sede continúa adquiriendo bienes en la zona por esos años ${ }^{52}$, y gracias a un documento de 1230 sabemos que contaba en Rabanal con un palacio para administración de sus explotaciones y rentas y residencia de dompnus Christoforus, que aparece asimismo co-

\footnotetext{
${ }^{44}$ FRL, I, p. 117 y II, doc. 3, interpreta que se refiere a cada campesino que tuviera heredades en prestimonio, pero, según J. SÁNCHEZ-ARCILLA, op. cit., p. 307, con el que coincidimos, se trata del tenente.

${ }^{45}$ CCL, doc. 1603.

${ }^{46}$ J. L. MARTín, Los origenes de la Orden Militar de Santiago (1170-1195), Barcelona, 1974, doc. 198.

${ }^{47}$ CCL, doc. 1846.

${ }^{48}$ CCL, doc. 1883.

${ }^{49}$ CCL, doc. 1916.

${ }^{50}$ CCL, docs. 1892, 1893, 1896, 1900.

${ }^{51}$ CCL, doc. 1901.

${ }^{52}$ CCL, docs. 1943, 1954, 1971, 1972.
} 
mo merino de ese lugar por parte del canónigo Gutierre Díaz, o de la obra de Santa María, de la que éste era tenente, junto a Munio Fernández y Juan Peláez, uillicantes ${ }^{53}$.

M. González Flórez destacaba la procedencia fenariega del caballero Diego López de Fenar, documentado en época de Alfonso IX ${ }^{54}$, que establecía a partir de su apellido. Esta tesis fue mantenida en obras posteriores de forma un tanto acrítica ${ }^{55}$, y de ella parecía derivarse una posible vinculación del personaje con la tenencia fenariega. Sin embargo, revisando los datos que poseemos, su conexión con el Valle de Fenar no parece tan segura. El óbito de un Diego López es recogido, junto al de Pedro Fernández de Castilla o Castellano, por Lucas de Tuy, que denomina a ambos potentissimi viri; se produjo en época de Alfonso VIII, lo que excluye toda confusión con Diego López de Haro, fallecido en $1238^{56}$. Coincide esta noticia con los Obituarios de la iglesia de León, que lo identifican expresamente como Diego López de Fenar, fechando su muerte en $1214^{57}$. Otros pasajes de la obra del Tudense hablan de Diego López, especialmente de su participación en la batalla de las Navas de Tolosa $(1212)^{58}$, aunque se trata de Diego López de Haro, señor de Vizcaya, y su apoyo a Alfonso IX de León en la toma de Alcántara, con licencia de su señor, el rey de Castilla ${ }^{59}$, que ha sido atribuida por la historiografía también a Diego López de Haro, pero que otros relacionan con nuestro Diego López de Fenar ${ }^{60}$. Si se refiere a él este episodio, habría que pensar en una procedencia castellana, pasando al servicio de Alfonso

\footnotetext{
${ }^{53}$ CCL, doc. 1972.

${ }^{54}$ M. GONZÁleZ FlóreZ, op. cit., León, p. 273.

${ }^{55}$ J. J. SÁnchez BAdiola, La comarca de La Robla, p. 56. J. Miranda PÉReZ-SEOANE, J. VALENZUElA Miranda, M. Álvarez Vélez, J. Llamazares, R. PÉrez, Estudio lexicológico y toponímico del Valle de Fenar, León, 1990, p. 18. Vid. J. PÉREZ GIL, «Imago maiestatis Marie: Vírgenes románicas de metal y repujadas en las diócesis de Astorga y León», XX Ruta C. del Románico, Pontevedra, 2000, pp. 107-111.

${ }_{56}$ «Eo tempore obierunt potentissimi viri Didacus Lupi, et Petrus Fernandi. Rex autem Castellae Adefonsus... obsedit fortissimum castrum sarracenorum Alcharaz et cepit ipsum, et reversus est in Castella... obiit in termino Arevali...» (J. PUYOL AlONSO, Crónica de España, de Lucas de Tuy (texto romanceado), Madrid, 1926, p. 416.

${ }^{57}$ «XIV Kal. Oct. Eodem die obiit Didacus Lupi de Fenal vir nobilis, \& armis strenuus, qui dedit B. Mariae Legionens. Sedis quadraginta marcas argenti \& anulos aureos, C. lapidibus pretiosis \& caeteros lapides pretiosos ad faciendam imaginem B. Mariae semper Virginis. ERA MCCLII.» (M. RISCO, Historia de la ciudad y corte de León y de sus reyes, Madrid, 1792, p. 375).

${ }_{58}$ "Exercitus autem christianorum sedit in monte nocte sequente, et illuscescente die, iussut rex Miramamolinus sarracenos tubis et tympanis excitare. Tunc reges christiani Ordinaverunt inter se, ut Didacus Lupi nobilis et strenuus cum nepote suo Sancio Fernandi quondam regis legionis filio, prima fronte exercitum praeiret.» (J. PUYOL, op. cit. p. 415). Refiriéndose a esta batalla, dice Ximénez de Rada: «...entre los príncipes castellanos Diego López con los suyos mandó la vanguardia...» (Historia de los hechos de España, ed. de J. Fernández Valverde, Madrid, 1989, p. 320).

${ }^{59}$ «Rex etiam Legionis... accepto a rege Castellae in auxilium sui potentissimo viro Didaco Lupi, sumpsit arma contra Sarracenos, et obsedit Alcantaram et cepit eam.» (J. PUYOL, op. cit., p. 416).

${ }^{60}$ M. GONZÁLEZ FLÓREZ, op. cit., p. 273.
} 
IX de León en 1213, y falleciendo al año siguiente. En tal caso, se trataría del personaje que aparece como testigo de la dotación del monasterio de Santa María de Bujedo (Burgos) en 1168, junto a otros miembros de la corte castellana ${ }^{61}$; y también el que confirma un documento de San Salvador del Moral, cercano a Palenzuela (Palencia), en $1194^{62}$.

No poseemos otras referencias a la tenencia de Fenar, salvo una curiosa noticia: en 1236, Fernando III concedía a su merino mayor en León, García Rodríguez Carnota, todos sus derechos en Brugos, que est in terra de Alua, inter Abzedo et Rauanal, entre otros diversos bienes sitos en Omaña, Luna y Gordón ${ }^{63}$. De no tratarse de un error del escribano, lo que no parece, vemos que Brugos, y quizá todo el Valle de Fenar, dependían entonces del territorio de Alba y la jurisdicción leonesa, situación que, no obstante, debió de ser transitoria.

\section{La señorialización del Valle de Fenar, I: los Quiñones de Alcedo}

La Baja Edad Media se abre para el Valle de Fenar con la confirmación que Alfonso X hace en 1254 del fuero de 1042, añadiendo una amplia exención fiscal a sus moradores, que quedaban libres de todo pecho, pedido, fazendera, fisco y servicio al rey, salvo moneda ${ }^{64}$. De la carta se deduce que el territorio se mantenía dentro del realengo, y que se inscribía en la política repobladora del monarca, de cara a mejorar la situación de sus vasallos y estimular de este modo la población de la comarca. Al parecer, tales exenciones venían a extender a todos los vecinos las concedidas por «el rey don Fernando con so fijo el rey don Alffonso» a los vasallos fenariegos de la sede legionense, de modo que «tote predicte hereditates sint libers et absoluti a modo de pecto, petito, yudaiga, rauso et homeçidio et fosado et fosadaria de omni fisco et foro regio de homni delito et seruiçio», como se afirma en el pleito que sostienen en 1284 el concejo de Fenar y el cabildo catedral contra Pedro González, don Gregorio y los demás sacadores y arrendadores de las rentas reales. Éstos habían entrado en Fenar y prendado a los vasallos de la iglesia en contra de las cartas dadas por el infante don Sancho, y en contra del pri-

\footnotetext{
${ }^{61}$ «Facta Charta sub Era milessima ducentessima sexta; sexto idus augusti. Regnante Rege Alfonso in Toleto et in Extrematura, atque in Castela... Huius rei sunt testes: Didacus Lupi de Fenar, testis. Rodericus Gutierrez mayordomus curiae, testis. Lupus Didaci merinus Regis, testis...» (Bujedo, 1892-1992: cien años al servicio de la escuela cristiana, Bujedo, 1992).

62 «Didagus Lopez de Fenar» (G. DíEZ MELCón, Apellidos castellano-leoneses (siglos IX-XIII, ambos inclusive), Granada, 1957, p. 242.

${ }^{63}$ J. GonZÁLEZ, Reinado y diplomas de Fernando III, Córdoba, 1980 y 1986, vol. III, doc. 571.

$1{ }^{64}$ FRL, II, doc. 3.
} 
vilegio citado. Por su parte, Juan Isídrez de Fenar, represente de todo el concejo de Fenar, mostró la confirmación de Alfonso X, de modo que los jueces de León, Martín Gil y Aparicio Martínez, fallan en su favor y ordenan el reintegro de lo prendado ${ }^{65}$.

No acabaron aquí los conflictos por este motivo. En 1364, se realiza el traslado de la confirmación que hiciera Fernando IV de la inmunidad que disfrutaban los vasallos de la iglesia en este valle y en otros lugares $^{66}$. Algunos años más tarde parece que se repiten los malentendidos, por cuanto, en 1442, Alfonso Navero, procurador del concejo de Fenar, se querella ante el rey que el concejo de Boñar no respeta sus fueros y privilegios y cobra en el valle pechos y servicios regios. Juan II confirma al año siguiente todos los privilegios fenariegos, y ordena al concejo de Boñar que los guarde y respete las exenciones de los vasallos del obis$\mathrm{po}^{67}$.

La situación jurisdiccional del Valle de Fenar se complica en el siglo $\mathrm{XV}$, debido al marcado proceso de señorialización territorial que caracteriza la política de mercedes de los Trastámara. La primera gran familia leonesa en aparecer en la escena política del valle durante la Baja Edad Media es la de los Quiñones de Luna, que percibían algunos tributos por cesión regia. Sabemos que, en medio de los conflictos dinásticos castellanos, Enrique IV concedía a Diego Fernández de Quiñones, conde de Luna, las alcabalas de diversos lugares, entre ellos el Valle de Fenar, que suponían, 2.000 maravedís anuales, a cambio de su renuncia a la Merindad Mayor de Asturias, aunque más tarde se las quita por haberse sumado el caballero leonés al partido del príncipe don Alfonso. Éste, titulándose rey, se las devuelve en $1465^{68}$. Sin embargo, será la rama de los señores de Alcedo la que se vea más directamente involucrada en la señorialización del valle.

Los orígenes de esta familia se remontan a don Ares Pérez de Quiñones, que recibe de Alfonso XI, en 1320, el lugar de Alcedo con sus términos y vasallos ${ }^{69}$. Las pretensiones de los Quiñones en el Valle de

\footnotetext{
${ }^{65}$ CCL, doc. 2434.

${ }^{66}$ C. Álvarez Álvarez, Colección documental del Archivo de la Catedral de León, vol. XII (1351-1474), León, 1995 (=CCL), doc. 3175.

${ }^{67}$ CCL, docs. 3550-3551. J. M. a SANTAmarta Luengos, Señorio y relaciones de poder en León en la Baja Edad Media. (Concejo y Cabildo Catedral en el siglo XV), León, 1993, p. 186, n. 156.

${ }^{68}$ E. Benito RuANO, «La merindad y alcaldía mayor de Asturias», Asturiensia Medievalia 2 3, 1979, pp. 275329 , p. 327 , doc. 20.

${ }^{69}$ MarquÉs de Alcedo y SAN Carlos, Los Merinos Mayores de Asturias (del apellido Quiñones) y su descendencia. Apuntes genealógicos, históricos y anecdóticos. Madrid, 1918, II doc. 137, p. 167.
} 
Fenar se centraron en el lugar de Brugos, donde Suero Pérez, bisnieto de don Ares, decía poseer ciertos vasallos, enfrentándose por ello en 1477 a la sede leonesa. Gutierre de Valle, canónigo y procurador del Cabildo, pide licencia al obispo para retirar del tribunal diocesano la demanda promovida contra dicho Suero Pérez sobre la propiedad, límites y jurisdicción de Brugos, con el fin de elevarla a otras instancias ${ }^{70}$. En 1484, fallecido ya don Suero, el prior de Santo Domingo, como juez apostólico, falla a favor del Cabildo, reconociéndoles el señorío sobre la aldea de Brugos, en ausencia y rebeldía de Catalina de Llanos, viuda de Suero Pérez, y de sus hijas, Leonor, mujer de Hernando de Vallecillo, Francisca, que lo era de Juan de Villamizar, regidor de León, María, esposa de Diego de Quiñones, señor de Sena, y Beatriz, casada con el licenciado Francisco Gómez de Tordehumos, oidor de la Real Audiencia ${ }^{71}$.

En 1487 se efectúan las partijas entre las cuatro herederas de don Suero, acentuándose los conflictos. Ese mismo año, y hasta 1503, los Reyes Católicos se ven obligados a sancionar a doña Leonor y su marido por los continuos abusos e intromisiones que venían cometiendo en el término de Orzonaga, apoyándose para ello en su casa de Alcedo, que habían «nuevamente» fortificado, pese a hallarse en términos de realengo, en la que se refugiaban tras sus correrías junto a otros «malfechores $»^{72}$. El lote correspondiente a dicha Leonor incluía, entre otros bienes $^{73}$, dos vasallos en Brugos de Fenar, García de Gete y Álvaro de la

\footnotetext{
${ }^{70}$ V. García LoBo, Colección documental del Archivo de la Catedral de León, vol. XIII (1475-1534), León, 2000 (=CCL), doc. 4012. Del carácter de don Suero da idea la confiscación de sus bienes por Juan II en 1449, por las fechorías cometidas por él en León junto a su cuñado, Lope Rodríguez de Lorenzana (MARQUÉS DE ALCEDO, op. cit., I, p. 206).

${ }^{71}$ CCL, doc. 4152.

${ }^{72}$ E. COOPER, Castillos señoriales de Castilla de los siglos XV y XVI, Madrid, 1981, doc. 210.

${ }^{73}$ Villardefrades con sus vasallos, fueros, pechos, jurisdicción civil y criminal, alta y baja, mero y mixto imperio; Alcedo con su casa y torre, valoradas en 35.000 mrs., más una huerta cerrada, en 4.000 mrs.; otra con sus perales, en 2.000 mrs.; el molino de Alcedo, en 10.000 mrs.; el suelo de la torre de Cutyello con tres vegadas de hierva de su prado, tres tierras y el piélago, todo ello en término de Santa Lucía de Gordón, y valorado en 4.500 mrs; la heredad de Huergas de Gordón, en 13.250 mrs.; en Vega de Gordón: el prado de «Vega Preciame» y otro más, en 4.360 mrs., el fuero de la huerta y el suelo del molino, en 10.000 mrs.; la heredad de Cascantes, que daba en renta cada dos años 4 heminas, en 800 mrs.; diversos bienes en Babia; las rentas del patronato de Santa Marina de Crespín, unas 16 heminas, en $5.333 \mathrm{mrs}$; la presentación de las parroquias de San Pedro de Llombera, San Antón del Puerto (Buiza), Vega de Gordón, San Pedro de Lago y Santa María de Lumajo. Los bienes de doña Leonor se citan en la testamentaría de su bisnieto Pedro de Quiñones, en 1609, entre ellos la casa y bienes de Alcedo y el lugar y puertos de Villardefrades, como bienes libres. Leonor deja luego a su hija Francisca, como mejora del tercio de sus bienes, las casas principales en Alcedo, dos huertos en el mismo pueblo, una heredad de cinco quiñones y un molino situado «en el río de Alva, cabe la hermita de la Magdalena, términos de el dicho lugar de Alcedo». En cuanto a Villardefrades, un 17’ $5 / 30$ era de Francisca, también como bienes libres, pero el resto fue herencia de María de Quiñones, esposa de Rodrigo de Argüelles y vecina de Granda (Pravia), a quien se lo compra en 1536 Antonio de Quiñones, padre del testador, que se lo deja a éste en herencia «por vía de vínculo y mayorazgo... término solariego.» Pedro de Quiñones deja a su hija Marcela en 1609 «el mi prado del fueyo con su cassa y todo lo en él incluso,
} 
Viñuela, que pagaban al año 20 mrs. y dos carros de leña, haciéndose constar que está pendiente de resolución el pleito que mantiene con la iglesia de León por los vasallos de Brugeros (sic), y con San Pelayo de Oviedo por ciertos heredamientos en el concejo de Gordón ${ }^{74}$.

¿Cuál fue el origen de estas posesiones? Es difícil asegurarlo, ya que son de muy diversa procedencia los bienes familiares. Por una parte está la concesión de Alcedo, que en épocas posteriores vemos reducida a la casa y otros derechos. Sabemos también que Suer Pérez de Quiñones, hijo del fundador, recibe de su primo Pedro Suárez de Quiñones, Adelantado Mayor de León, el señorío de Coladilla y Valle de Riazo (seguramente Valle de Vegacervera), en término de Cervera, en 1378, cesión reconocida por Carlos I en $1535^{75}$; Pedro Suárez le deja también en testamento el señorío de Villardefrades, en el concejo de Gordón, año $1388^{76}$, y probablemente también el patronato de la parroquia de Vega de Gordón, que comparte con San Pelayo de Oviedo y otros ${ }^{77}$. Enlazamos aquí con el amplio conjunto de heredades que las pelayas poseían en la comarca, procedentes de la donación que hiciera en su favor su antigua abadesa María González —o Gómez- de Gordón, hija de Suer Álvarez de Gordón y nieta de Juan Álvarez de Gordón ${ }^{78}$, con lo que nos remontaríamos en esta genealogía a los inicios del siglo XIII, si bien la presencia de la familia en la zona parece aún más antigua, a juzgar por el testamen-

sito en término de Alçedo, que está cercado de piedra y linda con camino françés y con prado del postigo y con tierra de las cadenas», pago éste de Alcedo cercano a Las Ventas, a los de la Magdalena y las Escadenas, y también al denominado «Huerto del Francés», junto a la calzada. Asimismo, los puertos de San Zervante, San Mamés y Fasgadillo (en Santa Lucía), con su jurisdicción civil y criminal, alta y baja, mero y mixto imperio, más la torre del término solariego del Villar, con jurisdicción civil y criminal, señorío y vasallaje, presentación de su iglesia de San Juan. Los puertos están en el término solariego de Villardefrades, lindando con los de La Pola, Faya de Santa Lucía, Vega de Gordón, Huergas y Llombera. Añade el puerto de Tabliza, en Villardefrades, lindero con Orzonaga, Coladilla, Llombera, y el puerto de Villa o Valle de María, también de la familia, con el que divide por la Orilla de Llana de Gallegos, Canto de la Devesa, Espino de la Vega y la Fonfría; y el de Sabugales, en la misma zona, junto a Llombera, Punta de la Tierra de los Casares, Canto de Vallina del Faedo y Sierra de Val de Cal (Archivo de los Marqueses de Montevirgen, Riolago, c. 46 y 50).

${ }^{74}$ Archivo de los Marqueses de Montevirgen, Quiñones, c. 7. Se trata de una transcripción del marqués de Alcedo, en la que dice, literalmente, «concejo de Gredo», que interpretamos como Gordón a la luz de otras fuentes.

${ }^{75}$ MARQuÉS DE AlCEDO, op. cit., I, p. 195, y II, doc. 145, p. 169. En el siglo XVI, los vecinos de Coladilla se lamentaban de los abusos cometidos por los señores de la casa de Alcedo, que exigían derechos señoriales y habían levantado allí horca y picota. Declaran que llevaron sus tributos — cabritos y corderos-, primero a las casas de los Quiñones en León y La Pola de Gordón, y luego a la de Alcedo, en el concejo de Alba (F. EsCOBAR GARCíA, El Ilustrísimo concejo de Gordón enriquece su historia, León, 1977, pp. 60-61 y 70-71). Este señorío pertenecía por herencia, en realidad, a doña María de Quiñones, hija de Velasco Pérez y María de Villasimpliz (A. y A. GARCÍA CARRAFFA, Diccionario heráldico y genealógico de apellidos españoles y americanos, Madrid, 1955, tomo 74, p. 69).

${ }^{76}$ MARQUÉS DE ALCEDO, op. cit., I, p. 32.

${ }^{77}$ F. J. FERNÁNDEZ CONDE, La iglesia de Asturias en la Baja Edad Media, Oviedo, 1987, p. 128.

${ }^{78}$ SPO, II, doc. 28 , y III, doc. 106. 


\title{
to del miles Fernando Gutiérrez, fechado en 1140. En él, deja a sus hijos Gutierre y Pedro sus heredades en Vega (¿de Gordón?), Olleros, Crespín y otros lugares, adjudicándole al último, que identifica como Pedro Gor- dón, su lóriga y sus brafoneras ${ }^{79}$.
}

\author{
En 1330, las monjas arriendan a Pedro Suárez de Gordón, por su \\ vida y por la de su hijo Álvar, e incluyendo el derecho de presentación de \\ sus iglesias, las heredades que poseen en Celada ${ }^{80}$, Vega de Gordón, Ce-
}

\footnotetext{
${ }^{79} \mathrm{CCL}$, doc. 1427. Probablemente sea el tronco común de una ramificada serie de derechos y heredades cuya complejidad no es fácil de desentrañar. En 1327, vende ciertas heredades en La Seca Aldonza Pérez, viuda de Juan Fernández de Llanos, personaje éste del que se afirma en 1338 que era divisero del río de ese lugar junto con sus hermanos y sobrinos, además de Fernando Fernández de La Seca, el cura Alfonso Martínez y otros (SMC, docs. 215, 228 y 275). Se cita asimismo como propietario en la zona Gonzalo Fernández de Llanos, con bienes en Cascantes, en 1341, y en Alcedo, donde compra en 1342 a Diego Centeno, hijo de Pedro Centeno, «caballero de las montañas», heredades que éste había adquirido de Álvar García de Llanos y su madre, Miasol, vecinos de Alcedo (Id. Ibíd., docs. 231 y 233). En 1434, el concejo leonés promueve una larga sucesión de pleitos contra otros tantos personajes por la atribución de unos derechos que el consistorio considera pertenecientes a su señorío y del rey, por hallarse dentro de su alfoz y jurisdicción. Los personajes en cuestión son María Fernández (¿de Llanos?), vecina de Cuadros, que se dice divisera del monte de La Seca y el río y sotos inmediatos al mismo; Catalina Alfonso, vecina de León, divisera del monte de Crespín y el río próximo; Pedro Suárez de Gordón, vecino de León, divisero también del monte de Crespín y el piélago que había acotado en el río; Gómez Fernández de Llanos, vecino de Llanos de Alba y divisero del monte y río de La Seca; Urraca Arias, viuda y vecina de León, divisera y señora del monte de Cascantes y Crespín; Velasco Pérez de Quiñones, señor de Alcedo y vecino de León — representado ante los jueces por Juan de La Seca-, divisero del monte y río de Crespín; la abadesa del monasterio de Santa María de Carbajal, divisera del monte y río de La Seca; Pedro Sánchez de Valdés, regidor de León y divisero del expresado monte de La Seca; y Pedro González de Villasimpliz, regidor de León y también divisero y señor del monte de La Llamilla (AHML, doc. 305. J. M. ${ }^{a}$ SANTAMARTA LUENGOS, op. cit., pp. 119-121). También aparece en esta documentación Diego de Castilla, divisero de Herreros (Villanueva del Carnero) en nombre de su hija María, que lo heredó de su madre, Catalina Fernández de Llanos, y ésta de sus antepasados, que se citan. Aunque el concejo interpreta que se trata de una atribución de derechos señoriales que no les corresponden, acotando bienes comunales o realengos cedidos a la ciudad, los demandados alegan que su condición de diviseros procede de sus antepasados, que venían ejerciéndola desde tiempo inmemorial, «así commo omes fijosdalgo en el tienpo que bivieran», aunque se muestran incapaces de demostrarlo de forma efectiva, por lo que el fallo es favorable a la ciudad, prohibiéndoles llamarse diviseros de dichos términos y acotarlos. ¿Estamos ante un caso de apropiación de bienes concejiles o, por el contrario, ante una reminiscencia de los heredes altomedievales y los infanzones posteriores, algunos ya muy presentes en estas riberas a finales del siglo XI, cuando pleitean con el obispo Pedro de León (CCL, doc. 1279) para mantener sus divisas, beneficios curados y derechos jurisdiccionales?

${ }^{80}$ Hoy término de La Robla, aparece como aldea en dos ventas de 1274 y 1275 localizadas en Cascantes, en las que se mencionan varios testigos procedentes de la misma: Alfonso Pérez, merino de Alba, su hermano Fernando, Domingo Tamanín, Domingo Domínguez, Pedro Gutiérrez y Juan, caballero (SMC, docs. 188 y 189). Sin embargo, hay referencias a confirmantes procedentes de este lugar en los años 1217 y 1219 (SMC, docs. 106, 110), con lo que su origen debe buscarse en las últimas décadas del siglo XII. Todavía en 1331 se cita a Juan Gutiérrez de Celada como testigo de una compraventa en Cascantes (SMC, doc. 222), aunque, a mediados de esa centuria, el Libro de Montería de Alfonso XI se refiere al monte del Sesteadero y Pelosas, diciendo que «...es bueno de puerco en ynvierno, y en verano, y son las bozerias la una por la loma («la Llomba») que es entre Fenal, y Val Feliz («Valfelices»), e la otra desde loma de Val de Feliz fasta la loma de Pelosas, e son las armadas lavna entre Pelosas, e Monte Gallinas, et la otra al espital de Celada» (Libro de la Montería que mandó escrevir el muy alto y muy poderoso rey don Alonso de Castilla, y de León, último deste nombre. Acrecentado por Gonçalo Argote de Molina, Sevilla, 1582, f. 38).
} 
rolleda ${ }^{81}$, Beberino, Crespín ${ }^{82}$, Olleros, San Martín de Cabo de Fontecha, Pobladura y Santa Lucía ${ }^{83}$. En 1350 se lo arriendan en similares términos a Pelayo Suárez, que da como fiadores a Martín González, hijo de Gonzalo Martínez de Pajares, y a Andrés Pérez, de Villardefrades, «que ye en Gordón ${ }^{84}$, mientras que en 1364 es Pedro Pérez de La Roure o La Robla, morador en Alba, quien los toma en arriendo $^{85}$, y Pelayo Suárez, hijo de Pedro Suárez de Gordón, nuevamente en $1369^{86}$.

La evolución posterior de este patrimonio es compleja. En 1490 y 1495, doña Íñiga Menéndez, abadesa de San Pelayo, llegaba a un acuerdo con las herederas de Suero de Quiñones, señor de Alcedo, con las que había mantenido diversos «pleitos e contiendas» por los heredamientos que el monasterio poseía en Beberino, Vega de Gordón y Santa Lucía, que otro documento sitúa en el concejo de Gordón, más Crespín, Celada, La Devesa y los cinco préstamos de Olleros. Al parecer, don Suero y sus antecesores habían ocupado tales bienes, causándoles graves perjuicios y gastos legales a las monjas, y ahora sus hijas se avenían a firmar una carta de censo y aforamiento de los bienes monacales «en el conçejo de Gordón e de Alva e Olleros». A tal efecto, doña Leonor y su marido, vecinos de Alcedo, otorgan poder a Alfonso Álvarez, clérigo y rector de Villasimpliz y Villardefrades, al igual que doña María el suyo, y que doña Beatriz, que recibe la oportuna licencia marital del licenciado Gómez de Tordehumos ${ }^{87}$.

En Celada, es el monasterio de Carbajal quien, a principios del siglo XVI, y quizá por permuta con San Pelayo, aparece cobrando un foro anual de un ducado a Pedro García y a sus herederos, vecinos de La Robla, por la «heredad y casa de Nuestra Señora de Zelada ${ }^{88}$, si bien un siglo más tarde se cita el santuario entre los que se hallan en el término parroquial de Alcedo, y a cuyo patronato se llaman los Quiñones de ese

\footnotetext{
${ }^{81}$ Se cita desde 1174, y parece que se halló en términos de Buiza de Gordón (V. y J. M. GARCÍA LOBO, Santa María de Arbas, catálogo de su archivo y apuntes para su historia, Madrid, 1980, docs. 81, 229, 397 y 983).

${ }^{82}$ Como se aclara en J. J. SÁNCHEZ BAdiola, Alba y Fenar, pp. 53-54, fue un poblado cuyo nombre se conserva en la amplia vega que ocupa toda la parte suroridental del término e Llanos de Alba, del que la leyenda afirma que fue destruido por una crecida del río, dividiéndose sus habitantes — y términos — entre La Devesa y Cascantes.

${ }^{83}$ F. J. Fernández Conde, I. Torrente, G. DE la Noval, El Monasterio de San Pelayo de Oviedo. Historia y Fuentes, Oviedo, 1978 (=SPO), II, doc. 28.

${ }^{84}$ Id. Ibíd., doc. 166.

${ }^{85}$ Id. Ibid., doc. 232.

${ }^{86}$ Id. Ibid., doc. 246.

${ }^{87}$ SPO, III, docs. 106, 112-114.

${ }^{88}$ G. M. ColOMBÁs, San Pelayo de León y Santa María de Carbajal, León, 1982, p. 255.
} 
lugar $^{89}$. En cuanto a Santa Marina de Crespín, les fue disputado por la parroquia de Llanos en el siglo XVII, pero sin éxito, pues el Catastro de Ensenada recoge aún el pago de los diezmos correspondientes a este beneficio simple, que cobraba José Manuel de Botas, cura de Alcuetas ${ }^{90}$. ¿Y Brugos? La sentencia emitida en 1489 por el bachiller en decretos y vicario general del obispado, Gil Sánchez Soriano, contra las hijas de Suero Pérez y Catalina González de Llanos, es clara al reconocer al Cabildo la jurisdicción civil y criminal, mero y mixto imperio y vasallaje de dicho lugar $^{91}$. Las dificultades que el Cabildo tenía para hacerse con el control de sus vasallos de Brugos se incluyen entre las súplicas que presenta a León X en 1517, junto con los vasallos de Robledo, y en las razones del pleito que promovió por entonces contra el concejo local, hasta que, en 1525 , ambas partes alcanzan un acuerdo por el cual se determinan las rentas que los vecinos debían pagar a la sede y la forma en que habrían de efectuarse ${ }^{92}$.

\section{La señorialización del Valle de Fenar, II: los Guzmán}

Otro frente se le abrió al Cabildo en tierras fenariegas durante 1466, cuando Enrique IV dona el Valle de Fenar y los de Cervera y Boñar a don Gonzalo de Guzmán, señor de Toral, con la justicia civil y criminal y el derecho de nombrar alcaldes, jueces y escribanos tal como pertenecían al rey, del que conocemos un traslado fechado en el siguiente año ${ }^{93}$. Seguramente, la concesión se refería a los derechos realengos, que en este territorio estarían desde tiempo atrás en manos del Cabildo leonés ${ }^{94}$. La reacción de éste se produce en 1476, por medio de una serie de acciones contra don Gonzalo, cuyo primer éxito será el compromiso al-

\footnotetext{
${ }^{89}$ MARQUÉS DE ALCEDO, op. cit., II, doc. 154, p. 170. La posesión de esa y otras ermitas provoca diferencias con el concejo de La Robla. En 1616, el militar Antonio de Quiñones, hijo de don Santacruz, segundón de la Casa de Alcedo, y sin descendencia, se comprometía a edificar a su cargo la capilla del monasterio en la Plaza del Grano de León, a condición de que sirviese en adelante para enterramiento de los señores de Alcedo, que se reservarían el derecho de presentación, debiendo proceder sus dos beneficiados, preferentemente, de Alcedo; en su defecto, serían de La Robla y, en último extremo, de la parroquia leonesa de N. ${ }^{a}$ Señora del Camino (G. M. COLOMBÁs, op. cit., pp. 315-316), y es en esta época cuando se evidencia la mano de los de Alcedo en algunas obras realizadas en el santuario.

${ }_{90}^{9}$ J. J. SÁNCHEZ BADIOLA, Alba y Fenar, pp. 53-54.

${ }^{91}$ CCL, docs. 4217 y 4809.

${ }^{92}$ CCL, docs. 4809 y $4988-4989$.

${ }^{93}$ CCL, docs. 3824 y 3838. Eran notarios públicos del concejo de Fenar Juan Martínez, en 1331 (SMC, doc. 222), y Gonzalo Alfonso, en 1379 (CCL, doc. 3258).

${ }^{94}$ Además de los vasallos y posesiones que la institución disfrutaba en todo el valle, acrecentadas poco antes por la donación que hizo en su favor en julio de 1461 el arcediano de Benavente, Ramir Núñez de Guzmán, dándole sus heredades «en Valeneva (probablemente Valcueva) e en Brugos e en Rauanal e en Robles e en otros lugares...». R. RODRÍGUEZ, «Extracto de actas capitulares de la Catedral de León», Archivos Leoneses, 24, 1958, pp. 332-333.
} 
canzado en abril de ese mismo año, por el que las partes admiten el nombramiento de jueces árbitros designados de común acuerdo, a los que someter el conflicto. Los jueces escogidos fueron Alfonso Ferrandes de Villalpando, Doctor en Decretos y arcediano de Valderas, y el bachiller Diego García de Valderas, vecino de la ciudad de León. Será por entonces cuando se tome declaración a diversos testigos acerca de tales derechos, especialmente «por dónde son los fitos e arcas e mojones del dicho valle e quántos e quáles son los lugares...», de quién son el señorío y la jurisdicción «de dicho valle e dichos lugares e de cada uno dellos asý de Naredo e Robredo e Solana, como de Candanedo e Brugos e Rauanal... cómo se ha exerçitado e usado la jurisdiçión çiuill e criminal en el dicho valle e en los dichos lugares dél e en cada uno dellos de dies e veynte e treynta e quarenta e çinquenta años a esta parte... »; igualmente, se inquiere sobre quién pone los jueces y por el lugar en que «...aya estado e esté forca alguna en el dicho valle e en qué lugar suele estar e quién la suele poner e por quién.... ${ }^{95}$.

El fallo es muy preciso en sus términos, al señalar, en primer lugar, que «segund lo ante nosotros mostrado e prouado, así por escripturas como por dichos e depusiçiones de testigos», la jurisdicción del Valle de Fenar, tanto civil como criminal, correspondía a la iglesia de León, en todos y cada uno de sus lugares, vasallos y heredamientos, «que son de la dicha iglesia e le pertenesçen». Del mismo modo, la iglesia y los jueces que en dicho valle han sido puestos por la misma «han estado e están en posesión e constunbre de muy luengo tiempo a esta parte, de más de quarenta e aun de çinquenta años de exerçer e usar la dicha jurisdiçión» en todos los lugares, vasallos y heredamientos de la iglesia. Los jueces, en cuanto esto, imponen perpetuo silencio a don Gonzalo de Guzmán.

Ahora bien, si la sentencia reconocía la jurisdicción de la sede sobre sus vasallos y suelos, igualmente hacía con los derechos del Guzmán sobre el lugar de Candanedo, que «es del dicho señor Gonçalo de Gusmán, fallamos que su merçed e aquellos de que en él uuo cabsa... han estado e están en posesión e costunbre de luengo tiempo a esta parte de poner por sí joes en el dicho lugar», el cual solamente podía juzgar y librar pleitos dentro de su término, pero no así fuera de él, en ningún otro lugar del valle, así fuesen civiles o criminales. Por el contrario, el juez que el deán y cabildo de la iglesia legionense ponían para el valle fena-

\footnotetext{
${ }^{95}$ CCL, doc. 3810. Archivo de la Catedral de León, numeración de Z. GARCÍA VILLADA, Catálogo de los códices y documentos de la Catedral de León, Madrid, 1919 (=ACL), doc. 8894/20.
} 
riego sí podía juzgar y librar pleitos civiles y criminales dentro del lugar de Candanedo, siempre y cuando se tratase de sus vasallos y heredamientos «posándose e sentándose a los jusgar e librar en casa o suelo o heredamiento que sea de los que la dicha iglesia tiene en el dicho lugar de Candanedo». Por último, fallan los jueces «que la forca que está en el dicho Valle de Fenar siempre ha estado e estado de muy luengo tiempo a esta parte, donde agora está, es a saber, en una cuestesuela e en un barrial blanco que está en la dicha costesuela que es entre Solana e Candanedo, e más çerca de Candanedo que non de Solana, e allí mandamos que se torne a poner e esté junto a una posa que está fecha para tomar lobos» ${ }^{96}$.

Pero la sentencia, pese a lo que tenía de conciliadora, establecía un escenario señorial excesivamente complejo, en especial en el lugar de Candanedo, que, por un lado, era reconocido como señorío de los Guzmán, pero, por otro, quedaba comprendido dentro del Valle de Fenar y sujeto a la jurisdicción de la iglesia. En 1476, doña María Osorio, mujer de Gonzalo de Guzmán, diciéndose señora de la mitad de Candanedo, con sus vasallos y jurisdicción, reclama sus derechos en dicho lugar, que teme perder por no haberse hecho compromiso firme entre las partes, y porque la parcialidad de los jueces les llevó a no expresar de forma clara que dicha jurisdicción es civil y criminal, permitiendo que el concejo fenariego la ejerza en Candanedo, sin atender a una sentencia anterior fallada a favor de doña Leonor Sánchez de Guzmán y don Juan de Villamayor $^{97}$. En 1484, Juana Ramírez de Guzmán, abadesa de Carrizo, afirma poseer como propio el señorío de Naredo y Robledo, en el Valle de Fenar, y deja el beneficio curado de estos lugares al monasterio de Carrizo, pero ejerciendo el derecho de presentación «in solidum» su hermano Gonzalo de Guzmán, corregidor de León y señor de Candanedo. En 1499, la abadesa acude a Naredo para ser reconocida como señora por el concejo, acompañada de varios hidalgos de la familia Quiñones ${ }^{98}$.

Pero, además, la sentencia contribuyó a abrir nuevos frentes, puesto que los vecinos del valle, tan preocupados por las intromisiones de los Guzmán como por la concentración de la autoridad señorial en manos del Cabildo, van a iniciar enseguida una serie de apelaciones ante la justicia real en defensa de sus derechos tradicionales. Las pretensiones el concejo de Rabanal de separarse de la jurisdicción capitular fueron

\footnotetext{
${ }^{96}$ ACL, doc. 4195 y 12069.

${ }^{97}$ CCL, n ${ }^{\circ} 4004$.

98 Información facilitada por Da . C. Casado Lobato. Vid. C. CASADO, A. CEA, Los monasterios de Santa María de Carrizo y Santa María de Sandoval, León, 1986, p. 14.
} 
reiteradamente desautorizadas por sucesivas sentencias pronunciadas por Real Chancillería de Valladolid. Rabanal y Fenar, se empeñan tenazmente en demostrar su pertenencia al realengo, y alegan incluso en 1484 ser behetría de mar a mar, enfrentándose al cabildo y muriendo un fenariego a manos de éste ${ }^{99}$. El proceso abierto coleaba todavía en 1499, cuando la Chancillería se pronuncia en favor de este último, que, en 1509, logra de la reina doña Juana la correspondiente carta ejecutoria, conociéndose también el traslado de la sentencia en 1519, que ponía fin al pleito promovido por el doctor Hernando Gómez de Ágreda, fiscal de sus Majestades, «e los conçejos, justiçias, regidores e omes buenos de Rauanal e Henal», por una parte, y el deán, cabildo y clérigos de la iglesia de León, por otra. El fallo absuelve a la sede de la demanda interpuesta por los primeros, y reconoce los derechos jurisdiccionales que tiene en dichos concejos, donde puede libremente poner alcaldes y merinos que atiendan la justicia civil y criminal, con la sola condición de que dichos alcaldes «sean vesinos del dicho conçejo de Henal e sus logares». En cuanto al oficio de escribanía, la sentencia dispone que dicho concejo pueda nombrar un escribano público del rey y la reina, «el qual con autoridad de los dichos deán e cabilldo de la dicha iglesia puedan usar e usen del dicho officio de escribano». Por último, se establece que «al tiempo que los dichos deán e cabilldo de la dicha iglesia pusyeren los dichos alcaldes digan que los ponen en nombre del Rey e de la Reyna nuestros señores e en nombre de la dicha iglesia como señora de los dichos conçejos» ${ }^{100}$. En 1502 se alcanza un acuerdo entre el cabildo leonés y el concejo Fenar sobre la elección de jueces por aquél ${ }^{101}$, y durante ese año y el siguiente, cabildo y concejo se enfrentan en pleito al corregidor de León, don Pedro Arias Dávila, por la jurisdicción del valle ${ }^{102}$, que en 1508 , en el pleito promovido por la abadía de San Isidoro contra los Guzmán de Aviados, ejemplifica cómo «...en esta tierra ay otros logares abbadengos desta misma calidad y constumbre, así como es el concejo de Fenar e otros, en que las yglesias cuyos son los logares ponen en ellos el juez por el Rey e por la yglesia, y así se llama Juez del Rey y de la Yglesia» ${ }^{103}$.

Pero los mayores problemas comenzarían el primer domingo de marzo de 1518. Ese día, como era costumbre, los vecinos del valle eligieron por juez para su seis lugares a Martín González, vecino de Candane-

\footnotetext{
${ }^{99}$ Archivo General de Simancas, $R G S$, mayo de 1484, fols. 24 y 39-40.

${ }^{100}$ ACL, doc. 1257 y 4200. CCL, doc. 4677. J. RoDRÍGUEZ, «El municipio de La Robla», p. 85.

${ }^{101}$ CCL, doc. 4550.

${ }^{102}$ Archivo General de Simancas, C. R., leg. 105-12.

${ }^{103}$ J. RODRÍGUEZ FERNÁNDEZ, «Algo sobre Vegacervera», TL, 54, 1984, pp. 61-72, p. 68.
} 
do, dándole posesión del oficio y el ramo. En julio, Gonzalo de Guzmán, «fijo mayor de Ramir Núñez de Guzmán... usando de juridiçión non la teniendo», según los fenariegos, ordenó a dicho juez que no osase ejercer su oficio, y a los hombres de Candanedo que bajo ningún concepto le reconociesen como tal ni obedeciesen. No contento con ello, el Guzmán entra en la aldea y ocupa una casa que allí tiene y que «apenas se puede morar», reparándola y fortificándola. Otro día de ese mes, domingo, Martín González, atemorizado, huye de Candanedo, dejando en funciones a su lugarteniente, Pedro Prieto, al cual Diego Díaz, «hijo de Arias Días alcaide de Aviandos (sic)», quitó la vara y encerró en la dicha casa «faziendo en ella cárçel privada, e que tomaron çiertos bueys e otros vienes del dicho juez e los metieron en la dicha casa, e clavaron las puertas de las casas de otros vezinos del dicho lugar porque non los fallaron dentro, amenazado que los avía de ahorcar e faziéndoles otras fuerças e ynjurias.»

Ante ello, el juez y los lugares de Fenar «que son todos un conçejo e ayuntamyento», se querellan ante la justicia real de los abusos cometidos por Gonzalo de Guzmán, Diego Díaz y las demás personas que intervinieron en los mismos. El procurador de don Gonzalo responde a las acusaciones que «los conçejos de los dichos lugares ni alguno de ellos desde tiempo ynmemorial ni de otro tiempo alguno no avían estado en posesyón de helegir entre sý una persona de los dichos lugares para que fuese juez en todos ellos, a lo menos, nunca avían estado ni están en posesyón de helegir en el dicho lugar de Candanedo ni la dicha yglesia de León de darle el ramo... e que verdad era que el dicho su parte e los otros señores que por tiempo avían seydo del dicho lugar cada uno en su tienpo, de tanto tiempo que no avía memoria de honbres en contrario, syenpre avían estado en posesyón, bel casy, de poner e tener puesto juez hordinario en el dicho lugar que avían traydo e trayan bara por los dichos señores a quien pertenesçía la jurisdiçión çibil e crimynal del dicho lugar de Candanedo, fasta tanto que de un mes e medio a esta parte los dichos lugares se avían entremetido a fazer juez vezino del docho lugar vasallo del dicho su parte, el qual havía açebtado el ofiçio e resçibido la bara, e que el dicho su parte, syn escándalo alguno, continuando e defendiendo su posesyón, le envió a mandar que no truxiese la bara ny usase ni exerçiese juridiçión en el dicho lugar de Candanedo, e que por lo aver tomado e se aver entremetido en lo que no podía ni devía se avía ausentado sabiendo que el dicho Gonçalo de Guzmán yva al dicho lugar, e le fueron sequestrados los vienes; e porque la casa que dezían hera del dicho su 
parte y lo avía sydo de sus anteçesores e que hera casa llana... que no estava cayda salvo una esquna que se avía reparado tan presto. E por el tiempo que los dichos lugares se entremetieron a helegir al dicho Martín Gonçales se avían contradicho la eleçión por parte del dicho Gonçalo de Guzmán que poco tienpo antes avía adquirido el señorío del dicho lugar, e estava puesto juez en él por su predeçesor. E porque el dicho Gonçalo de Guzmán avía ydo al dicho lugar con syete u ocho peones e que los vezinos de los dichos lugares se avían ayuntado más de çent honbres armados, e que fueron al dicho lugar e llevaron con bara de juez a un sustituto del dicho Martín Gonçales, vasallo del dicho su parte, e que él, usando de su posesyón, le hizieran dexar la vara...»

En agosto, la Real Chancillería nombra y apodera como juez pesquisidor al licenciado Juan de Salmerón, escribano de cámara de los reyes, al que habrá de ir a buscar al «lugar de Vega de Ariença del conçejo de Humaña... Gonçalo Xuares, vezino del lugar de Robledo, ques en el dicho conçejo de Fenar, por sý e como procurador que se dixo del dicho conçejo, vezinos e moradores del dicho valle.» Ante él y el licenciado Cristóbal Uceda, que le acompaña, se irán produciendo las declaraciones de las partes, que repiten casi textualmente los argumentos ya señalados, salvo el acento que el procurador del Guzmán pone en que «la dicha juridiçión çibil e criminal del dicho lugar de Candanedo es e pertenesçe al dicho mi parte e no al dicho conçejo del dicho Valle de Fenar ni a otra persona alguna, e pues es destinto e apartado con él, y éste no entra ni entró ni anduvo en tiempo alguno con el dicho Valle de Fenar ni con el dicho conçejo ni lugares de él, ni tiene la dicha comunión en lo que toca a la dicha juridiçión». La sentencia se leyó el 24 de diciembre, y en ella se le negaba taxativamente la justicia criminal a Gonzalo de Guzmán, se desautorizaba su actuación en el lugar de Candanedo el julio anterior, y se le condenaba a pena de destierro del Valle de Fenar, la devolución de los bienes prendados, las costas y los salarios del licenciado Salmerón y su escribano, Pedro de Piña, y el el allanamiento de las puertas de la «casa e torre» de Candanedo, prohibiéndole hacer en ella nuevas obras sin licencia de los reyes, so pena de desmantelarla ${ }^{104}$. No obstante, en cuanto a la justicia civil, el licenciado Salmerón considera que «devo declarar e declaro que la dicha juridiçión çibil es e pertenesçe al dicho conçejo e a su juez en el dicho lugar de Candanedo, quedándole al dicho Gonçalo de

\footnotetext{
${ }^{104}$ En Candanedo, bajo las escuelas, se conservan unos cimientos que, según la tradición, pertenecieron a un castillo de época de los moros. J. A. GUTIÉRREZ, op. cit., pp. 188-190, los cree posiblemente romanos, al ser de mampostería y dura argamasa, de unos $110 \mathrm{~cm}$. de grosor. Junto a los muros aparecieron restos de vasijas.
} 
Guzmán su juez en el dicho lugar de Candanedo para sacar sus fueros e derechos, el qual pueda oyr los pleitos çibiles entre los vezinos del dicho lugar que de su boluntad quisyeren... el qual no pueda traer bara de justiçia». La de Cristóbal de Uceda es similar, salvo que, según él «la dicha juridiçión çivil del dicho lugar de Candanedo pertenesçe al dicho Gonçalo de Guzmán e pertenesçe estar en posesyón, él e sus pasados, de poner juez en el dicho lugar... el qual, syn bara de justiçia, pueda sacar e juzgar sus fueros e derechos e los pleitos çibiles del dicho lugar... syn que en esto se pueda entremeter ni entremeta el juez del dicho conçejo».

Tampoco en esta ocasión quedaron conformes las partes, apelando la sentencia el cabildo y el concejo fenariego, representado por Arias Díaz, vecino de Candanedo, que actúa en su nombre y el de sus lugares de Candanedo, Robledo, Solana, Rabanal y Brugos; Martín Sánchez, juez del dicho concejo, y Pedro Prieto, teniente de Martín González. Para ellos, don Gonzalo de Guzmán nunca tuvo derecho señorial ni jurisdicción alguna sobre Candanedo, y prueba de ello era que jamás los había ejercido. Don Gonzalo la apeló también, defendiendo su derecho a la jurisdicción no sólo civil, sino también criminal en dicho lugar, la cual, si no se había ejercido de forma efectiva, se debió, según él, a no existir delincuentes sobre quienes hacerlo. Las discrepancias continúan hasta 1526, cuando una nueva sentencia revoca la pronunciada por el licenciado Uceda y niega la justicia civil en Candanedo a Gonzalo de Guzmán, estableciendo que aquélla, así como la criminal y los pregones, se hagan en nombre de los reyes. Una nueva apelación por parte del cabildo, descontento con la omisión de su señorío, culmina con la sentencia definitiva, que establece que «la juridiçión çibil e criminal del dicho lugar de Candanedo se use y exerçite, e los pregones que se dieren sean en voz e en nonbre de su Magestad e del deán e cavildo de la dicha yglesia de León juntamente e non de otra manera», expidiéndose la correspondiente carta ejecutoria en El Portillo el 24 de octubre de $1527^{105}$.

$* * *$

Deán y cabildo salían triunfantes del proceso, siéndoles reconocidos sus derechos jurisdiccionales sobre todo el valle, que, de este modo, salvaba la amenaza de usurpación por parte de dos de los principales linajes de la nobleza leonesa, y lograba permanecer unido frente a los reiterados intentos de desmembramiento de lugares suyos, como Rabanal,

${ }^{105}$ CCL, docs. 4853, 5028. ACL, doc. 1780. 
cuyas pretensiones «secesionistas» hemos visto, o Naredo, que no se cita, por cierto, en el pleito. El Memorial de los derechos que el Cauildo tiene en el Valle de Fenar, manuscrito del siglo XVI que se conserva en el Archivo catedralicio, informa muy precisamente sobre cuáles eran las prerrogativas de la sede y las costumbres administrativas del concejo. Éste, conforme al texto, cuenta entonces con seis lugares que están juntos y se llaman, «començando desde el río que está en medio de Neredo y Robres, Neredo, Robredo, Solana, Candanedo, Rauanal, Brugos y aquí acaba todo el Valle de Fenar», precisándose que «no ay algund lugar que se llama Fenar mas todos juntos se llaman del Valle de Fenar». En esos lugares, el señorío y vasallaje de todos sus vecinos pertenece a la iglesia de León desde tiempo inmemorial, sin distingos entre aldeas, la cual percibe allí dineros, tributos, yantares y gallinas cada año, en concreto, 60 y más carretadas de leña al año, 10.000 maravedís en dineros, las tercias de los diezmos y el patronato de todas las parroquias del valle, cien gallinas y más de los fueros de los vecinos de sus lugares.

La justicia civil y criminal y el mero y mixto imperio corresponden, asimismo, a la sede, y la costumbre de elegir jueces y alcaldes es «que se juntan todos los dichos lugares y los ydalgos y buenos onbres dellos en cada año el primero domingo de março çerca de la yglesia parrochial de Sant Christóbal del lugar de Solana e nombran fasta seys personas dellos mesmos, las que ellos entienden que son más hábiles y sufiçientes para ser juezes, y aquel día mesmo enbía ally la yglesia de León un canónigo el qual escoge entre los dichos seys uno o dos que sean juezes y exerçan toda la dicha jurisdiçión del dicho año dándoles las varas de justiçia o poniéndoles un ramo en la mano en señal que aquél o aquéllos hase juez, sea verdad que como el Rey nuestro señor tenga la soberana jurisdiçión en todos sus reynos, quando el dicho canónigo les da las varas o el dicho ramo dize que les faze juezes en nombre del Rey y de la dicha yglesia y cabildo de León, y así nombrados los dichos por jueses les toma juramento el dicho canónigo sobre una cruz o sobre los Santos Evangelios que bien fiel y enteramente y syn pasyón alguna exerçerá la justiçia en todos los lugares de dicho valle, y después quando dexare el ofiçio de juez en cabo del año por veynte días ha de faser resydençia ante el juez subçesor y satisfaser a los querellosos sy ovo en su tiempo así de la negligençia como de dolo y maliçia». En cuanto al nombramiento de escribanos, «se tiene tal forma que el dicho día que se ponen los juezes nombran los del dicho conçejo tres o quatro notarios sy los ay en el valle y sy no en las comarcas, y el dicho canónigo... asý commo escoge el juez 
escoge de los notarios nombrados aquel que él vee que es más sufiçiente para exerçer el dicho ofiçio de notariato» ${ }^{106}$.

Sin embargo, este panorama era cierto sólo parcialmente, puesto que Quiñones y Guzmanes lograron mantener algunos derechos en tierras fenariegas. Por el Catastro de Ensenada sabemos que Candanedo satisfacía anualmente un foro de 2016 maravedís y 34 carros de leña, uno por vecino, o su equivalente en dinero, a los duques de Uceda, señores de Toral, y que las alcabalas de todo el valle eran pagadas a los marqueses de Lorenzana ${ }^{107}$. En cuanto a los beneficios curados, el Becerro de presentaciones afirma que los de San Miguel de La Ylze y San Salvador de Fenar no pertenecían a la sede, sino a nobles patronos hereditarios, que no identifica. En 1568 Isabel Rojas, señora de Toral, presenta a Juan Costilla como rector de San Miguel de Candanedo ${ }^{108}$, aunque al poco aparecen en el mismo diversas familias locales ${ }^{109}$, cuyo derecho de presentación no sabemos si se alternaba con el de los Guzmán o se produjo algún tipo de transmisión. En Naredo y Robledo, la abadesa de Carrizo aparece en las ternas para nombramiento de párrocos, y en 1901 lo hace junto con la reina regente, en nombre de su hijo Alfonso XIII, designando a Fernando Miranda Suárez como cura de la nueva «parroquia de San Salvador de Robledo» ${ }^{110}$.

Por otro lado, el señorío jurisdiccional de la sede sobre el Valle de Fenar iba a durar poco tiempo, pues a lo largo de los siglos posteriores, todo el territorio aparece formando parte del realengo ${ }^{111}$, eligiendo los vecinos anualmente los cargos concejiles - jueces ordinarios ${ }^{112}$. J. Rodríguez supone que tales derechos de orden señorial serían abolidos por

\footnotetext{
${ }^{106}$ CCL, doc. 5290. ACL, doc. 12878.

${ }^{107}$ AHPL, CME, Rabanal, Candanedo, Solana. Los padrones de fines del XVI atribuyen a la comarca 148 vecinos, unos 650 habitantes (pecheros en T. GoNZÁLEZ, Censo de población de las provincias y partidos de la Corona de Castilla en el siglo XVI, Madrid, 1829, p. 28; pero, en el Censo de Castilla de 1591. Vecindarios, Madrid, 1984, p. 328, 126 hidalgos, 18 pecheros y 4 clérigos). El Vecindario de Ensenada, 1759, vol. 4, Madrid, 1991, indica un descenso hasta los 500-520 habitantes, que a finales de ese siglo rondarían los 635 (Censo de 1787. Floridablanca. Vol. 3: Comunidades autónomas de la submeseta norte, parte occidental, Madrid, 1989).

${ }^{108}$ C. Álvarez, J. A. Martín Fuertes, Catálogo del Archivo de los Condes de Luna. León, 1977, doc. 609.

${ }^{109}$ Según P. MADOZ, Diccionario geográfico, histórico, estadístico de España y sus posesiones de Ultramar, Ed. Facsímil, Valladolid, 1983, las familias Díez y Laiz, ésta oriunda, sin duda, de La Yz. La documentación las confirma, junto con otras, como presenteras del beneficio en los siglos XVII y XVIII (AHDL, F. Beneficial, c. 3119).

${ }^{110}$ AHDL, F. Beneficial, c. 13064 y 14757.

${ }^{111}$ Algún documento del siglo XVII sitúa el concejo de Fenar en la jurisdicción de Vegacervera, lo que pudo deberse a una confusión (AHDL, F. Beneficial, c. 13065 y 14760).

${ }^{112}$ P. MADOZ, op. cit.
} 
Felipe II, como ocurriera con otros de la iglesia, mediante indemnización desconocida, manteniéndose las propiedades puramente patrimoniales ${ }^{113}$.
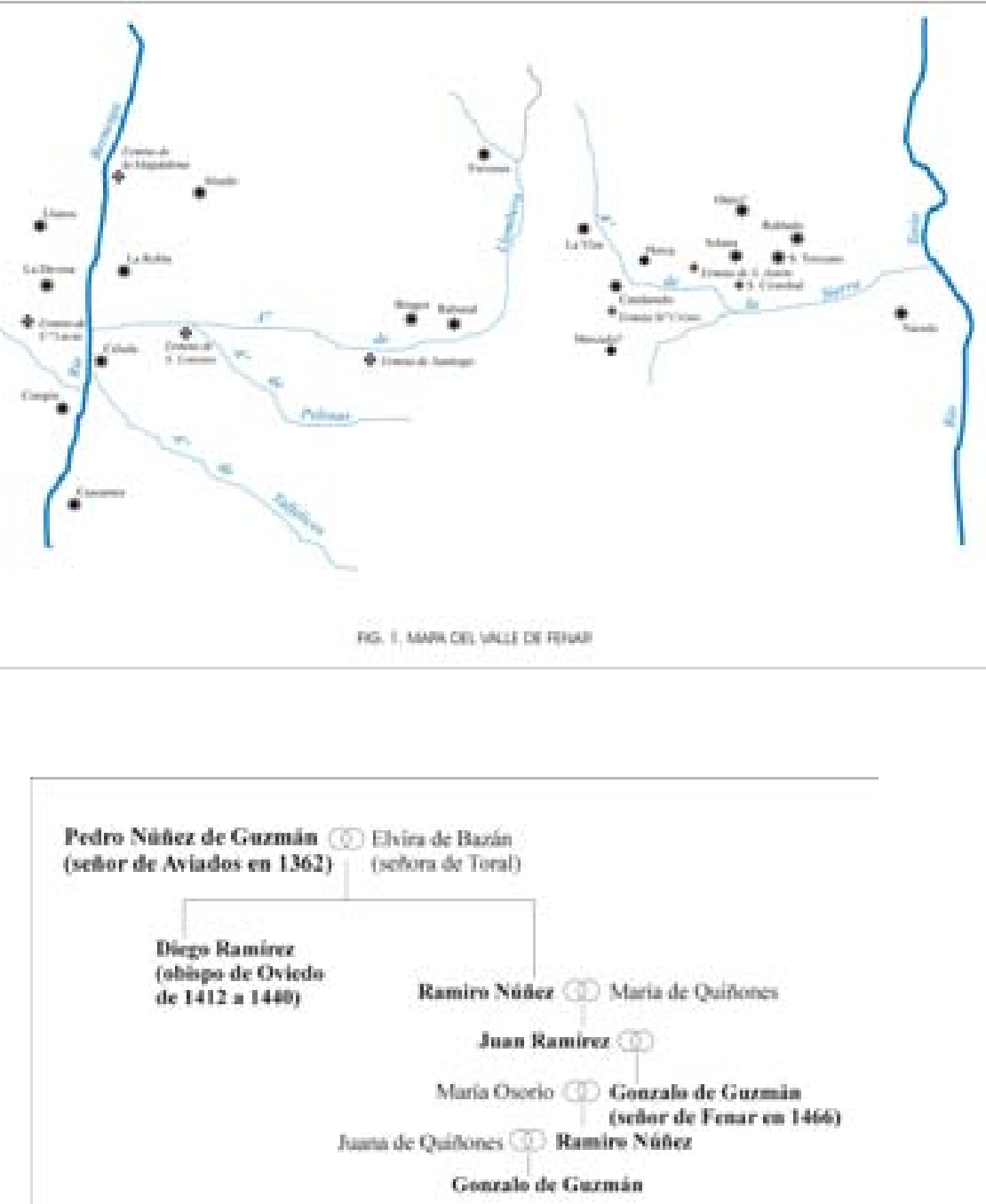

FG. 3. GEVROGIA DE LOS GUDWW

${ }^{113}$ J. RoDRÍGUEZ, «El municipio de la Robla», p. 85. 


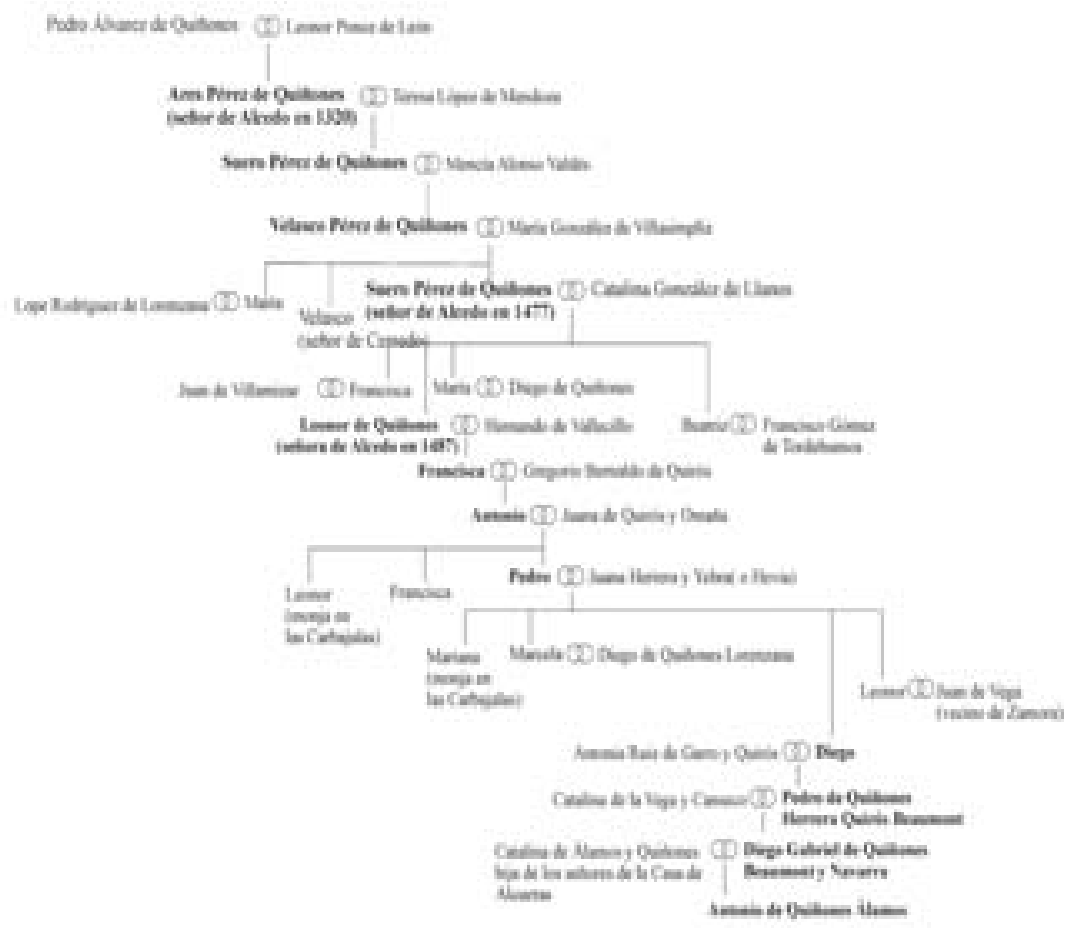

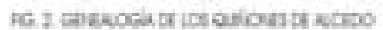


